Litvak A. I., Mykhaylenko V. L., Fedorchenko R. A. Medical staff morality. Journal of Education, Health and Sport. 2020;10(5):249260. eISSN 2391-8306. DOI http://dx.doi.org/10.12775/JEHS.2020.10.05.026

https://apcz.umk.pl/czasopisma/index.php/JEHS/article/view/JEHS.2020.10.05.026

https://zenodo.org/record/3890220

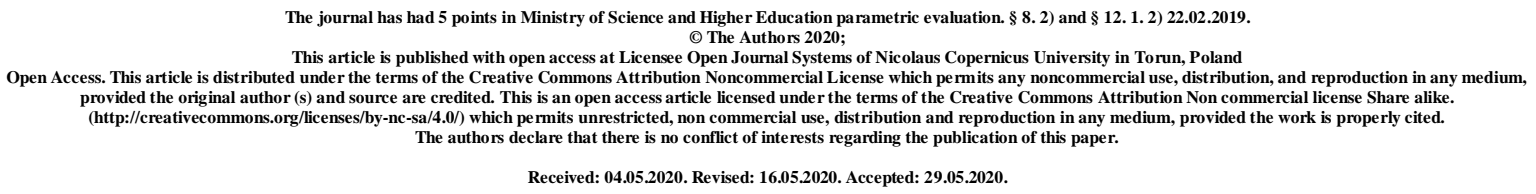

UDK 614.253.1/.5-029:17

\title{
MEDICAL STAFF MORALITY
}

\author{
*A. I. Litvak, **V. L. Mykhaylenko, ***R. A. Fedorchenko
}

\author{
*ORIPA NAPA under the Prezident of Ukraine \\ **Odessa National Medical University \\ ***Zaporizhzhia State Medical University
}

Litvak Akim I., MD, PhD, Associate Professor, Associate Professor of Humanities and SocioPolitical Sciences Department Of Odesa Regional Institut of Public Administration of the National Academy for Public Administration under the President of Ukraine

e-mail: akymlitvak@gmail.com

Mykhaylenko Volodymyr L., MD, PhD, Associate Professor of Department of Rehabilitation Medicine, Odessa National Medical University, Odessa, Ukraine

e-mail: vlmykhaylenko@gmail.com

Fedorchenko Ruslana A., MD, PhD, Associate Professor of Department of Hygiene and Ecology, Zaporizhzhia State Medical University, Ukraine.

e-mail: ruslanafedorchenko2016@gmail.com

\section{Abstract}

The medical help is considered to be full when medical staff not only use medical and diagnostic technology properly, but also follow the ethical rules. The research showed questionnaire to be a good method of diagnostic for both medical staff ethical potential and the individual employee's one. The scale for assessing group ethical preferences is considered to be effective also. The data resulted in a high level of ethical values and behaviour for only every eleventh respondent include. The majority of respondents, more than two-thirds, showed an average level and one of five - showed a low ethical level, mainly due to the low 
ethics of males. The ethical learning is an urgent and indispensable task of the medical environment in public professional organizations. The ethical trainings for different social groups (as males, females doctors and the medical staff) should be distinctively different in content and occurred in each medical organisation annually. The medical ethics has become a professional competence factor of medical staff and it should be taken care of, both the public and administrators, heads of medical institutions at all levels of government.

Key words: morality; medical staff; questionnaire; doctors; nurses; women; men; ethical level.

\title{
МОРАЛЬНІСТЬ МЕДИЧНОГО ПЕРСОНАЛУ
}

\author{
* А. І. Литвак, ** В. Л. Михайленко, *** Р. А. Федорченко \\ *ОРІДУ НАДУ при Президентові України \\ **Одеський національний медичний університет \\ ***Запорізький державний медичний університет
}

\section{Резюме}

Вважається, що медична допомога повноцінна тоді, коли медичний персонал додержується усіх етичних норм і правил, а не тільки правильно і адекватно використовує лікувально-діагностичну технологію. Дослідження показало результативність використання анкетування, як засобу діагностики рівня етичного потенціалу медичного закладу і окремого співробітника, а також запропоновану шкалу оцінки групових етичних уподобань. За результатами дослідження тільки кожен одинадцятий респондент показав високий рівень етичних цінностей і поведінки. Найбільша частина людей - більш як дві третини, показали середній рівень і кожен п’ятий респондент продемонстрував низький рівень етичності, головним чином, за рахунок низької етичності чоловіків. Навчання етичним правилам, нормам і поведінки є невідкладним i неодмінним завданням лікарського середовища, громадських професійних організацій. Етичні тренінги для різних соціальних груп (лікарів чоловіків, жінок і середнього медичного персоналу) за змістом мають суттєво відрізнятися i відбуватися в кожній медичній організації, хоча б раз на рік. Можна стверджувати, що медична етика стала фактором професійної компетентності медичного персоналу і нею слід опікуватися, як громадськості, так і адміністраторам, керівникам медичного закладу на всіх рівнях управління. 
Ключові слова: моральність; медичний персонал; анкетування; лікарі; медичні сестри; жінки; чоловіки; рівень етичності.

Recent years saw the rapid interest increase both to ethics and its role in the professional sphere, business, and management. First of all, this is related to an understanding of the organizational process in management and its influence on effectiveness at all. Secondly, an organization as a socio-cultural system with humans in the centre can be also included. Thirdly, ethics becomes a professional competence factor of medical staff. Some experts say organization with high ethical level are prosperous, while other with low level are prone to decline or could disappear at all. Ethics is connected with a moral individual's culture. It can be defined as a result of moral experience and an individual's development, that presupposes a level of social experience development; an ability to consistently use the values, norms, rules, and principles of ethics in peoples' relations; a readiness for selfimprovement.

Professional activity views people as its main object and creates a complex relation system determined by relations morality. Such a system includes a) doctor's attitude to the subject of work (doctor-patient - employee); b) colleagues' relations; c) doctor's attitude to society. These relationships are studied by professional ethics. Specifying the general moral principles and norms of such relations is the so-called "professional" morality per a particular type of professional activity. Such morality appears with the social division of labour which started the separation process of socio-professional groups. With this process appeared, need in relationship regulation became obligatory. Especially between professionals and consumers. The study of these aspects makes our work relevant.

The study's purpose was to study the influence of the state on the moral values and moral choices of medical staff - doctors and nurses. The study object was the normative acts of the state and international organizations, as well as medical workers as carriers of morality and ethical behaviour. The study subject was ethical standards and the commitment of an individual or a group to ethical behaviour during medical activities at work. Our study used some legal-based research methods in qualitative content analysis, a sociological survey with questionnaires, statistical data processing, structural indicators, data grouping, table construction, graphical, and comparison methods.

The literary sources analysis has shown the words "ethics", "moral" and "morality" are interchangeable in the general cultural vocabulary. Ethics - is a branch of philosophy studying the moral sense, origin, development, and functioning in relations between people and the 
duties arising from these relations. For the first time, the term "ethics" was used by Aristotle, who understood it as a philosophy of the moral behaviour of people. Ethics is the science that studies morality. Ethics considers communication as an urgent necessity; the most important need of people; a way of human existence and life activity. Morality - is a system of values, norms, and rules recognized and regulated by society. Morality is a set of requirements and prohibitions. Albert Schweitzer, a German theologian, and physician wrote: "The fundamental principle of morality is respect for life. Good is in being sympathetic and helpful to others. Evil is not to show sympathy to any creature and cause pain or death to them" [13]. The difference between law and morality is that morality is based on a person's beliefs, and the law is based on coercion by the power of the state. Morality - is a person's characteristic combining kindness, collectivism, hard-working, discipline, decency, honesty, truthfulness, justice, and regulating human behaviour.

Medical ethics appeared as a branch of General Ethics and should be considered as a specific manifestation of it. Medical ethics - theory on moral foundations for medical professionals, about their humanism as a necessary condition for successful patients' treatment. Ethical principles in medicine are unchangeable. Although each medical specialty has its ethical features, all they are united by General Ethics. The international code of medical ethics was adopted by the General Assembly of the World Medical Association in 1949. The code was amended in 1968, 1983, and 1994. In general, it defines the unethical behaviour of the doctor and his/her duties for patients.

The international code of medical ethics consists of only two pages. They display four sections that set out the main requirements for the correct behaviour of the doctor and define what he/she should not do in any case when performing his/her professional duties. The code consists of the following sections: doctor's general duties; definition of what is unethical for the doctor; doctor's obligations towards the patient; doctor's obligations towards everyone else. The international code of medical ethics proclaims that: "a doctor should act only in the best interests of the patient especially when he/she applies such types of medical care that may weaken the physical or mental condition of the patient". This document reflects the behaviour essence of a doctor: "He/She must respect the patient or colleagues' rights, be honest and sincere in communicating with them".

October 2005 witnessed UNESCO adopt the "Universal Declaration on Bioethics and Human Rights". This document refers to the medical workers' principles and duties as: human dignity, human rights and respect of human integrity; equality and justice; beneficence and not harm; respect cultural diversity and pluralism; non-discrimination and stigmatization; 
independence and individual responsibility; the principle of informed consent (including those who cannot consent); privacy and confidentiality; solidarity and cooperation; social responsibility; benefit-sharing; protection of future generations; the environment and the biosphere principles [2]. The declaration addresses the countries of the world and it can be used by individuals in their practical actions. This document has become a reference point for the development of ethical relations in the current health care system, which should be equal to doctors and nurses, medical organizations, and public authorities. Bioethics becomes an interdisciplinary branch of knowledge by studying the moral, philosophical, theological, legal, and social issues that accompany the development of biology and medicine. It also covers medical ethics and extends beyond it. Biomedical ethics examines the range of problems wider than classical medical ethics do. The central idea in bioethics is built on attitude to life and death, and what can be considered as the highest value.

Ukrainian democratic transformations were accompanied by the adoption of several state documents on moral, ethical, and deontological regulation in medicine. That helps the government to influence on medical staff morality. Article 76 of the Basic legislation of Ukraine on Health Protection is called "Medical Oath". It says that graduates of medical specialties of higher educational institutions take the "Medical Oath" [9]. Besides, there is a text of the "Medical Oath", which was approved by the Presidential Decree on June 15, 1992 [5]. According to M. M. Tishchuk, Ukrainian words "prisyaga" and "klyatva" have a single Slavic origin and mean "oath". There is no text of Oath as stated in "Fundamentals". But the text was approved by the Ukrainian President several months before the relevant law on "Fundamentals Of Ukrainian Legislation On Health Protection" [12]. Receiving the doctor's title the graduate vows: "to devote all knowledge, strength, and skills for the human health protection and improvement, treatment and prevention of diseases; to provide medical care for all who need it; to preserve medical secrecy; to observe the rules of professional ethics...". Ethical norms of the Medical Oath can be traced in: 1) the recognition of medical duty, prevention and treatment of diseases, 2) the obligation to provide medical care to the patient, which is associated with the demonstration of mercy, 3) the obligation to take care of the benefits for the patient, 4) the obligation to be fair to all people, 5) the obligation to observe medical secrecy, 6) the obligation to observe generally accepted standards of professional morality and collegiality, 7) constantly improve in their profession. The document analysis shows all important norms of medical ethics, accepts deontological principles, considers international experience, and ethical standards laid down in the so-called "Hippocratic Oath". For comparison, let's give its main content, referred to: the obligations of teachers, colleagues, 
and students; the obligation to provide medical care to the patient; the guarantee of non-harm, the negative attitude to euthanasia, abortion; the refusal of medical professionals from intimate relationships with patients, and medical secrecy. The first known professional moral code was drawn up by Hippocrates (460-370 BC). This famous paper generalizes all to be known for humanity from the previous generations and before. It contains certain rules truly connected with doctor's professional activity from one side ("I will not operate on someone who suffers from kidney stones, but I will present it to experienced practitioners"), and abstract notions that leave the freedom of moral choice from the other ("I will use all my strength to help the sick and prevent injustice and harm"). A doctor's professional duty is a moral duty to his/her patients, colleagues, teachers, and students [6].

A. Savitska noted the main aim of Oath is to express the medical workers' public duty. Duties are the work obligations that received legal consolidation. She observed these norms as a combination of legal influence and high morality. They represent such legal norms that determine a doctor's behaviour in the field of his professional activity, not only in terms of law but also in morality.

The "Fundamentals of Ukrainian Legislation on Health Care" has the Article 78 on "Professional Responsibilities of Medical and Pharmaceutical Workers". This article includes Clause «Г» which says: "Medical workers are obliged to comply with the requirements of professional ethics and de-ontology and to maintain medical secrecy". The medical secrecy remains present for doctors and other medical staff even now a day. Article 40 says medical staff and other individuals knowing about somebody's illness, medical examination, and their results, intimate and family aspects of a patient's life, have no right to disclose this information, except in cases provided by law. The concept of "Medical Secrecy" has very deep historical roots, which dates back to the time of Hippocrates. Today, the medical secrecy is viewed as one of the medical confidentiality branches. That expands the circle of people responsible for its remaining. People trust medical professionals some personal data willingly, thinking that it remains undisclosed. Today, medical secrecy transformed into the legal norm. The disclosure of medical secrecy entails criminal liability (Article 145 of the Ukrainian Criminal Code) if the disclosure caused serious consequences (for example suicide, exacerbation of illness due to anxiety).

Special medical legislation, in various areas of medical activity, also adds to the regulation of behaviour in the relationship between doctor and patient. The main legislative acts include the law: "On Blood Donation and Its Components", "On Transplantation of Organs and Other Human Anatomical Materials", "On Psychiatric Care", "On the Prohibition 
of Human Reproductive Cloning", "On the Prevention of Acquired Immunodeficiency Syndrome (AIDS) and Social Protection" and other. This list also should include the National program on health: "HEALTH 2020: Ukrainian Dimension".

The Ethical Code of Ukrainian Doctor was adopted and signed at the All-Ukrainian Congress of Medical Organizations and X Congress of the All-Ukrainian Medical Society (UMS) in the Evpatoria September 27, 2009 [3]. The Ethical Code of Doctor - is a compilation of ethical norms and rules of doctor's behaviour with patients, colleagues, representatives of other medical and pharmaceutical professions and corporate groups in the course of professional activity. The introduction begins with the phrase: "Human's life and health are the main fundamental values. A doctor's activity is directed on saving people from the very beginning of their life. Such activities also require humanism, respect, compassion and complicity, benevolence, charity and mercy, patience and mutual trust, decency, and justice. A doctor must not forget the main judge for his/her professionalism always be a conscience". "The Ethical Code Of Ukrainian Doctor is still a perfect declaration of Ukrainian medical society. Its usage (or neglect) does not in itself produce any legally significant consequences ", said O. G. Rogova, lawyer, speaking about the document from the legislative side [10]. In 2019, the Ethical Code celebrated its 10-years anniversary. On this subject a professor O. Volosovets appointed: " For that time, the Code became a basis for medical science development according to providing patient-centred approach and resolving of ethical situations at work and doctor's professional development [7, p. 55]. N. M. Boychenko believes that the "Code..." has become a kind of guidance that systematically sets out the moral principles, norms, and rules used in medical practice [7, p. 59]. At once O. Musiy and S. Nechaiv marked the text and the content of the Code should be discussed and improved [7, p. 57]. O. Gordienko highlighted the Ethical Code would work entirely only if medical selfgovernment appeared nominally and legally [7, p. 56].

Also, there is a Nurse Ethical Code adopted on the 1st Ukrainian Nurse Congress (in 1999, Chernivtsi). The preamble says: "Ukrainian nurses comply with the Ethical Code, realizing the importance of moral and ethical norms, as the representatives of the medical sphere which are guided by modern ethical and regulatory documents of international medical organizations" [4].

There is one tradition of considering the definition of good behaviour as the ethics main question. Especially, what can be defined as good or bad behaviour. This served as the basis of conducting a sociologic poll for medical workers. We have used a questionnaire of English researchers [14]. This questionnaire is built on the right-wrong principle and contains 
15 typical situations described different choice problems of ethical norms in professional reality. For measuring ethical relations, respondents had to determine their attitude to the described situation on a four-point scale, where "0" - strongly disagree and "3" - strongly agree. The results helped to define the personal ethical mark. All personal ethical marks were divided into three levels: high, average, and low. It created a definite profile characterizing the group of people connected by one feature. All respondents answer the questionnaire independently and anonymously. The research studied 104 doctors with 42 men and 62 women with 24 female nurses from different organizations.

It showed that only every eleventh respondent $(8.6 \pm 2.49 \%)$ out of 128 people had a high level of ethical values and behaviour. So we expected more. The majority of respondents - more than two thirds $(70.3 \pm 4.04 \%)$, showed an average level and every fifth respondent $(21.1 \pm 3.61 \%)$ showed a low ethical level, mainly due to low ethics from the male group.

The difference between the percentage of respondents who found themselves together at a certain level of ethics (high, average, low) for all medical professionals has high statistical confidence. According to the data, the respondents' marks showed a high tolerance for the majority of medical professionals to unethical behavior during professional duties. These data proved certain neglect to one self's or others' behavior, which completely destroy the moral norms and rules.

In our observations, there was also a difference in assessments of the self-choice behaviour, which showed a different ethical level between men and women, as well as the difference between people with different education (secondary special and higher) (table 1).

Table 1

Doctors' distribution from different medical institutions by sex and education

\begin{tabular}{|l|c|c|c|c|c|c|}
\hline \multicolumn{7}{|c|}{128 people } \\
\hline \multirow{2}{*}{$\begin{array}{l}\text { Ethical } \\
\text { level }\end{array}$} & \multicolumn{2}{|c|}{ Males doctors } & \multicolumn{2}{c|}{ Females doctors } & \multicolumn{2}{c|}{ Medical nurses } \\
\cline { 2 - 7 } & individuals & $\%$ & individuals & $\%$ & individuals & $\%$ \\
\hline high & 2 & 4.8 & 8 & 12.9 & 1 & 4.2 \\
\hline average & 26 & 61.9 & 46 & 74.2 & 18 & 75 \\
\hline low & 14 & 33.3 & 8 & 12.9 & 5 & 20.8 \\
\hline Total & 42 & 100 & 62 & 100 & 24 & 100 \\
\hline
\end{tabular}

This allowed us to assume that factors that can influence the moral choice and behaviour of a medical worker may be: the employee's gender (male or female) and the person's education (secondary education of nurses, higher education of women doctors). The obtained data indicate women be more ethically educated than men, as well as female doctors 
are more ethically educated than female nurses. Some women's and men's behaviour in the same circumstances may differ significantly and this must be taken into account during the ethical training of medical staff.

The study showed the questionnaire's effectiveness as a means of diagnosing the potential ethical level of a medical institution and an individual employee. That confirmed the possibility of using a questionnaire to diagnose various factors affecting ethical relations in the organization, as well as the proposed scale for evaluating group ethical preferences. The ethical rules training is an urgent and indispensable task for the medicinal environment and public professional organizations. Ethical training sessions for various social groups (male and female doctors; nursing staff) should differ significantly in content and take place in each medical organization annually. Every year should see an annual ethical conference in institutions of all the regions. Medical ethics can be defined as a general factor of professional competence for medical staff. It should be taken into account by the public, administrators, managers of medical institutions at all levels of management.

Professor T. V. Mishatkina in her observations and analysis concluded: "The main provisions knowledge of the Code of Ethics and constant reference to it can contribute to the formation of certain stable deontological stereotypes in the minds of doctors, so provides deontological morality of the doctor as a result" [1, p. 254]. All existing impact tools can increase the potential of ethics for an organization and individual employees. That fact discussed by analysts and experts can be divided into three main groups: informational, which can be attributed to internal means of influence (ethical code, ethical maps, ethical behaviour training), organizational (the creation of ethical committees, conferences, and round tables), and expert-analytical, which can be attributed to external activities (social audits, ethical expertise, consulting).

The research allowed us to formulate the following proposals:

- It is necessary to introduce a regular annual assessment of the staff ethical values level in each medical institution through a questionnaire.

- It is necessary to organize the study and discussion of ethical rules and standards in each institution through debates, conferences and round tables, which should become an indispensable issue in the plans for the ongoing improvement of medical staff in the workplace.

- It is necessary to create Ethical Committees on a voluntary basis that would deal not only with control and expert issues but also with organizational and methodological activities. 
- It is necessary to introduce schools of ethical behavior, especially necessary for young professionals.

- It is necessary to train medical staff in ethical behavior, taking into account the characteristics of previous education and gender.

- It is necessary to develop programs for the ethical development of medical staff in medical institutions.

The world community has always attached great importance to the moral and ethical factors in medicine. Medical care is considered to be complete when medical staff not only correctly and adequately use medical and diagnostic technology but also comply with all ethical norms and rules. Leading representatives of the medical profession have always noted the humane nature of the medical profession, demanded mercy, honest, and dedicated acting of their professional duties according to their vocation and conscience.

\section{Література:}

1. Биомедицинская этика: учеб. пособие / под ред. Т. В. Мишаткиной, С. Д. Денисова, Я. С. Яскевич. - Минск, 2003.

2. Всеобщая декларация по биоэтике и правам человека // Организация Объединенных Наций по вопросам образования, науки и культуры // UNESCO, 2006.

3. Етичний кодекс лікаря України. // Газета здоров’я України. 2009. № 19 (224). C. 30-31.

4. Етичний кодекс медичної сестри України. URL: http://uamed.net/dok/codex.html.

5. Клятва лікаря. // Указ Президента України від 15 червня 1992 року N 349.

6. Колісник-Гуменюк Ю. І. Формування професійно-етичної культури майбутніх фахівців у процесі гуманітарної підготовки в медичних коледжах: монографія / Юлія Колісник-Гуменюк. - Львів : «Край», 2013. — 296 с.

7. Матеріали ХУ11 з’їзду Всеукраїнського Лікарського Товариства. Полтава 14 - 16 листопада 2019 р. Одеса. В-во Бартенєва, 2019. - 216 с.

8. Международный кодекс медицинской этики. Принят 3-й Генеральной ассамблеей ВМА, Лондон, Англия, октябрь 1949 г., - Режим доступа: http://www.uapravo.net/akty/postanowa-main/akt8pqdx0b.htm

9. Основи законодавства України про охорону здоров'я : закон України від 19.11.1992 p. № 2801-XII. База даних «Законодавство України» URL: http://zakon.rada.gov.ua/cgi-bin/laws/main.cgi?nreg=2801-12 
10. Рогова О. Г. Застосування етичних кодексів в медицині / О. Г. Рогова // Вісник Академії адвокатури України. 2012. № 2 (24). С. 30-38.

11. Стеценко С. Г. Медичне право України: підручник. / за ред. д. ю. н. С. Г. Стеценка. К.: Всеукраїнська асоціація видавців «Правова едність». 2008. - 507 с.

12. Тищук M. М. Клятва VS Присяга лікаря. Кому служить лікар? / М. М. Тищук // ХУ1 Конгрес Світової Федерації Українських Лікарських Товариств (БерлінКиїв 18-23 серпня 2016 року) : матеріали. Одеса видавництво Бартенєва, 2016. С. 1417.

13. Швейцер, А. Благоговение перед жизнью / А. Швейцер; сост. и посл. А. А. Гусейнова; общ. ред. А. А. Гусейнова. - М., 1992.

14. Is Your (Ethical) Slippage Showing? by Lowell G. Rein, copyright September 1980

\section{Literature:}

1. Biomediczinskaya e'tika: ucheb. posobie / pod red. T. V. Mishatkinoj, S. D. Denisova, Ya. S. Yaskevich. - Minsk, 2003.

2. Vseobshhaya deklaracziya po bioe tike i pravam cheloveka // Organizacziya Ob`edinenny`kh Naczij po voprosam obrazovaniya, nauki i kul tury`// UNESCO, 2006.

3. Etichnij kodeks li'karya Ukrayini. // Gazeta zdorov'ya Ukrayini. 2009. \# 19 (224). S. 30-31.

4. Etichnij kodeks medichnoyi sestri Ukrayini. URL: http://uamed.net/dok/codex.html.

5. Klyatva li karya. // Ukaz Prezidenta Ukrayini vi`d 15 chervnya 1992 roku N 349.

6. Koli`snik-Gumenyuk Yu. I'. Formuvannya profesi`jno-etichnoyi kul turi majbutni`kh fakhi vczi`v u proczesi gumani`tarnoyi pi`dgotovki v medichnikh koledzhakh: monografi`ya / Yuli`ya Koli`snik-Gumenyuk. — L`vi`v : «Kraj», 2013. — 296 s.

7. Materi`ali KhU11 z'yizdu Vseukrayins`kogo Li`kars`kogo Tovaristva. Poltava 14 - 16 listopada 2019 r. Odesa. V-vo Bartenyeva, 2019. - 216 s.

8. Mezhdunarodny`j kodeks mediczinskoj e`tiki. Prinyat 3-j General`noj assambleej VMA, London, Angliya, oktyabr` 1949 g., - Rezhim dostupa: http://www.uapravo.net/akty/postanowa-main/akt8pqdx0b.htm 
9. Osnovi zakonodavstva Ukrayini pro okhoronu zdorov'ya : zakon Ukrayini vi`d 19.11.1992 r. \# 2801-KhI'`. Baza danikh «Zakonodavstvo Ukrayini» URL: http://zakon.rada.gov.ua/cgi-bin/laws/main.cgi?nreg=2801-12

10. Rogova O. G. Zastosuvannya etichnikh kodeksi`v v mediczini` / O. G. Rogova // Vi`snik Akademi`yi advokaturi Ukrayini. 2012. \# 2 (24). S. 30-38.

11. Steczenko S. G. Medichne pravo Ukrayini: pi`druchnik. / za red. d. yu. n. S. G. Steczenka. K.: Vseukrayins`ka asoczi aczi ya vidavczi`v «Pravova edni`st`». 2008. - 507 s.

12. Tishhuk M. M. Klyatva VS Prisyaga li`karya. Komu sluzhit` li`kar? / M. M. Tishhuk // KhU1 Kongres Svi`tovoyi Federaczi`yi Ukrayins`kikh Li`kars`kikh Tovaristv (Berli n-Kiyiv 18-23 serpnya 2016 roku) : materi`ali. Odesa vidavnicztvo Bartenyeva, 2016. S. 14-17.

13. Shvejczer, A. Blagogovenie pered zhizn`yu / A. Shvejczer; sost. i posl. A. A. Gusejnova; obshh. red. A. A. Gusejnova. - M., 1992.

14. Is Your (Ethical) Slippage Showing? by Lowell G. Rein, copyright September 1980 